\title{
Sol-Gel Synthesis and Characterization of $\mathrm{TiO}_{2} \mathrm{Nano}$ Films in the Building of Dssc
}

\author{
D. Maheswari ${ }^{1}$, P. Venkatachalam ${ }^{2}$ \\ ${ }^{I}$ Department of physics, Muthayammal Technical Campus, Rasipuram, TamilNadu. \\ ${ }^{2 *}$ Department of Physics (DDE), Annamalai University, Annamalainagar, TamilNadu-608 002.
}

\begin{abstract}
Dye-sensitized solar cells (DSCs) promise a short energy-payback time and offer a potential lowcost alternative to conventional photovoltaic devices based on semiconductors. This work describes the effort which has mainly been developed on DSSC solar cells with suitable dye for light harvesting and interfacial electron transfer processes with nano crystalline wide band-gap semiconductors. The photo anode preparation has been done by means of $\mathrm{TiO}_{2}$ nano films by sol gel method using TTIP as precursor, and coated in ITO plate by doctor blading technique. The mesoporous $\mathrm{TiO}_{2}$ thin film was characterized by XRD, SEM, and TEM. A novel unique combination of electrolyte is used (0.6 M of EMII, BMII and PMII, 0.1 M LiI, 0.05 M I2 in acetonitrile). The best performance was demonstrated by the DSSC having a $16 \mu m$-thick $\mathrm{TiO}_{2}$ back electrode, which gave a solar energy conversion efficiency of $1.83 \%$ under the light of intensity of $100 \mathrm{mWcm}^{-2}$.
\end{abstract}

Key words: Electrolyte, Indigo Dye, Sol-gel, $\mathrm{TiO}_{2}, \mathrm{XRD}$,

\section{Introduction}

As the most promising photo catalyst, $\mathrm{TiO}_{2}$ materials are expected to play an important role in solving many serious environmental and pollution challenges [1]. $\mathrm{TiO}_{2}$ also bears tremendous hope in helping ease the energy crisis through effective utilization of solar energy based photovoltaic devices. Titanium dioxide $\left(\mathrm{TiO}_{2}\right)$ has been widely investigated as a key material for applications in photovoltaic cells, batteries, chemical sensing, optical emissions, photonic crystals, catalysis, photo catalysis and environmental purification. Anatase $\mathrm{TiO}_{2}$ electrodes are used in solar cells, lithium batteries and electro chromic devices owing to its good storage capacity, cycling-stability and safety against overcharging [2]. Non-toxicity, environmental compatibility and low price are other practical advantages of $\mathrm{TiO}_{2}$

In DSSC, the light absorption and the separation of the electrical charges happens in different process. The light absorption process is performed by dye molecules, and the separation of the electrical charge is done by the nanocrystal inorganic semiconductor TNP (titanium dioxide nanoparticles) that has a wide band gap [3]. This $\mathrm{TiO}_{2}$ working electrode film is an important part of DSSC. It can be prepared by various methods such as solgel, chemical vapor deposition (CVD) and sputtering. Sol-gel process is a favorable method for preparing $\mathrm{TiO}_{2}$ nano particles, since the composition, particle size, film thickness, and porosity of $\mathrm{TiO}_{2}$ can be easily controlled by adjusting parameters such as sol concentration, hydrothermal growth temperature, and sintering condition. We prepared $\mathrm{TiO}_{2}$ naoparticles by Sol-gel- process and its characterization has been studied.

Although the DSCs using noble metal complexes as dye sensitizers provided relatively high efficiency, there are many disadvantages for using noble metals in the DSCs, such as limited resource, high cost, and longterm unavailability. In nature, flowers, leaves, and fruits show various color and contain various natural dyes which can be extracted by simple procedure. Therefore, researchers pay more and more attention to natural dyes owing to their low cost, non toxicity, and full biodegradation [4-11]. In our work, we synthesized natural indigo Dye and used as sensitizer. Using this dye, the incident monochromatic photon-to-current conversion efficiency (IPCE) is impressive (IPCE) value exceeds $80 \%$ in the wavelength range between $230-284 \mathrm{~nm}$.

The presence of a liquid electrolyte demands a perfect seal in order to avoid leakage and evaporation of the solvent. Nonetheless, such perfect seals are difficult to obtain, usually the use of a liquid component results in poor long-term stability. Many efforts have been investigated to overcome this drawback by replacing the liquid electrolyte by room temperature ionic liquids, organic and inorganic hole transport materials, polymer and gel electrolytes. DSSC using polymer gel electrolytes present a better performance when compared to the same device assembled with a classical polymer electrolyte. So a new combination of redox electrolyte, consisting of [0.6 M of EMII (1- Ethyl-3- methyl - imadazolium iodide), BMII(1-butyl-3-methyl-imadazoliumiodide) and PMII (1-propyl-3-methyl-imidazoliumIodide), 0.1 M LiI, 0.05 M I2 in acetonitrile was introduced into the cell through one of two small holes drilled in the counter electrode.

Counter electrode with high electrochemical activity is an important requirement of efficient DSSCs. Cobalt sulphide is used as Counter electrode. 


\subsection{Materials}

\section{Experimental}

Titanium (IV) isopropoxide is used as (TTIP, 97\%, Aldrich), precursors for preparing titanium dioxide by sol-gel method. The adjustment of $\mathrm{pH}$ was done by adding reagent grade $\mathrm{NaOH}$ (Aldrich). Triton X-100 (Aldrich) and Polyethylene glycol (PEG M.W=20,000, Aldrich) were used as binders, and natural dye Indigo dye was used as the sensitizer. The electrolyte $0.3 \mathrm{M} \mathrm{LiI}, 15 \mathrm{mM} \mathrm{I2,} 0.5 \mathrm{M}$ PMII, BMII, PMII polymer gel electrolyte was purchased from Aldrich. Acetic acid and ethanol were purchased from Aldrich, $0.5 \mathrm{mM}$ Cobalt Sulphide (Aldrich). All other solvents and reagents were analytical grade quality, purchased commercially, and used without any further purification. ITO conducting glass $(20 \sim 30 \Omega / \mathrm{cm} 2$, Aldrich, Co., LTd) was selected as the substrate for $\mathrm{TiO}_{2}$ film.

\subsection{Synthesis of nano crystalline anatase $\mathrm{TiO}_{2}$ powder}

$\mathrm{TiO}_{2}$ mesoporous nanoparticles were prepared by titanium tetraisopoxide (TTIP) $27 \mathrm{ml}$ in $100 \mathrm{ml}$ of $\mathrm{n}$ heptane as a solvent and stirring for $2 \mathrm{~h}$. Then $7.98 \mathrm{ml}$ of double distilled water was added drop wise and the molar ratio of TTIP: $\mathrm{H}_{2} \mathrm{O}$ was maintained as $1: 5$, and then this sample was aged for $72 \mathrm{~h}$ at room temperature, and then dried at $70{ }^{\circ} \mathrm{C}$ for $12 \mathrm{~h}$ and calcinated at $400{ }^{\circ} \mathrm{C}, 600{ }^{\circ} \mathrm{C}$ and $700{ }^{\circ} \mathrm{C}$ in the ambient air [12]. The obtained $\mathrm{TiO}_{2}$ were studied through XRD, SEM and TEM. The sample heated at $400^{\circ} \mathrm{C}$ was used in the preparation of photo anode because it has anatase nano crystalline structure of particle size $10 \mathrm{~nm}$.

\subsection{Preparation of $\mathrm{TiO}_{2}$ Photo anode}

For the preparation of mesoporous $\mathrm{TiO}_{2}$ nanocrystalline film, first the titania slurry was prepared by the incremental addition of $2 \mathrm{ml}$ aqueous Triton $\mathrm{X}$ solution to $0.5 \mathrm{~g}$ mesoporous $\mathrm{TiO}_{2}$ powder in a mortar under vigorous grinding by the pestle and the prepared uniform slurry was coated on ITO glass by a doctor blade technique. Triton $\mathrm{X}$ acts as a binder to prevent cracking of film and control the porosity during preparation of film. After natural drying at room temperature, the thin film was calcined in static air at $400{ }^{\circ} \mathrm{C}$ for $30 \mathrm{~min}$.

\subsection{Fabrication of DSSC}

The mesoporous titania electrode was immersed in the ethanolic solution of indigo dye at room temperature for $24 \mathrm{~h}$ in the dark. The electrode was then rinsed with ethanol. The counter electrode was prepared by spin coating $5 \mathrm{mM}$ solution of Cobalt sulphide in Indium Tin oxide plate and sintering for $30 \mathrm{~min}$ at $900^{\circ} \mathrm{C}$. The resulting dye adsorbed film was clipped with the counter electrode and then redox electrolyte containing $0.3 \mathrm{M} \mathrm{LiI}, 15 \mathrm{mM} \mathrm{I}$, $0.5 \mathrm{M}$ (PMII+EMII +BMII) and $0.2 \mathrm{M}$ Poly ethylene glycol in acetonitrile, was introduced into the cell through one of two small holes drilled in the counter electrode through capillary action [13].

\section{Characterization}

The crystallinity and crystal phase of the titania film was evaluated by Bruker D8 Discover XRD with diffracted beam graphite monochromator at $50 \mathrm{kV}$ and $40 \mathrm{~mA}(\mathrm{Cu} \mathrm{K} \alpha$ with $\lambda=1.54187 \AA)$.

The film thickness was measured by a profilometer (Veeco, dektack3). The microstructure of films was studied by transmission electron microscopy (TEM) Jeol JEM 2100 Resolution: $1.4 \mathrm{~A}^{\circ}$ (Lattice) to $1.9 \mathrm{~A}^{\circ}$ and Scanning Electron Microscope (SEM) HITACHI Model S-3000H [14]. The photo-electrochemical properties of the solar cell were studied by recording the current-voltage characteristics of the cell under an illumination of 1 Sun $\left(100 \mathrm{~mW} / \mathrm{cm}^{2}\right)$ using a $150 \mathrm{~W}$ Xenon lamp (Polaronoix).

\subsection{Results and discussion 3.1.1 XRD Analysis}

The XRD patterns of the synthesized $\mathrm{TiO}_{2}$ nano powders calcined at $400^{\circ} \mathrm{C}, 600^{\circ} \mathrm{C}$ and $800^{\circ} \mathrm{C}$ for $3 \mathrm{~h}$ are shown in Fig. 1, which revealed the presence of anatase and/or rutile phases of $\mathrm{TiO}_{2}$ depending on the calcination temperatures. At $400^{\circ} \mathrm{C}$ and $600^{\circ} \mathrm{C}$, it is clear that a peak was recorded at $2 \theta$ value of $24.882^{\circ}$, which corresponds to crystalline anatase phase of $\mathrm{TiO}_{2}$. The crystallite size of $\mathrm{TiO}_{2}$ was calculated from a halfvalue width of the XRD peak at $2 \theta=25.3$ using Scherrer's equation.

$$
D=\frac{0.94 \lambda}{\beta \cos \theta}
$$

Equation (1)

where $K(0.94)$ is the shape factor, $\lambda$ is the $\mathrm{x}$-ray wavelength, $\beta$ is the line broadening at half the maximum intensity (FWHM) in radians, and $\theta$ is the Bragg angle, D is the mean size of the ordered (crystalline) domains, which may be smaller or equal to the grain size [14-16]. 


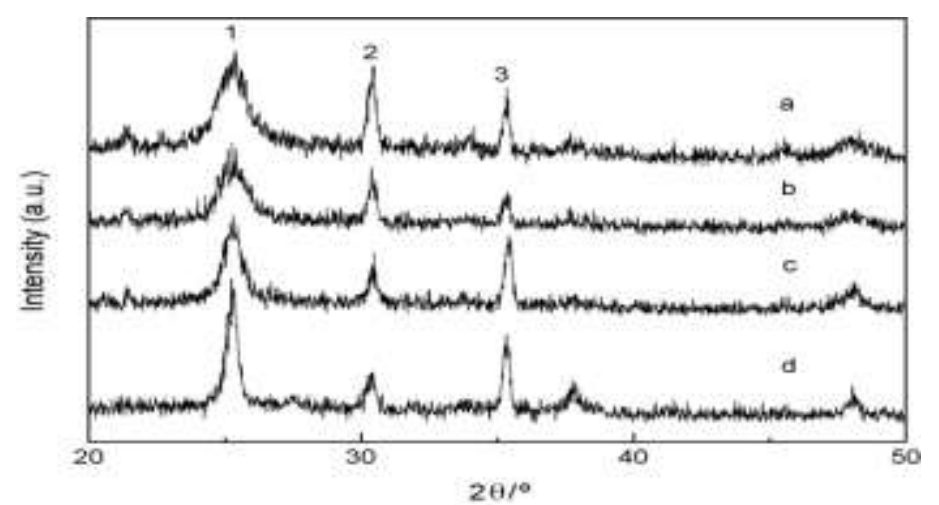

Fig.1: XRD diffraction of $\mathrm{TiO}_{2}$ calcining at $400^{\circ} \mathrm{C}(\mathrm{a}), 600^{\circ} \mathrm{C}(\mathrm{b}), 800^{\circ} \mathrm{C}$ (c) and $\mathrm{P25}$ (d)

Using the Scherrer's formula mentioned above at $\lambda=1.5418 \mathrm{~A}^{\circ}, \beta=0.774^{\circ}, 2 \theta=24.92^{\circ}$, the crystallite size of the synthesized $\mathrm{TiO}_{2}$ powder was found to be $10.5 \mathrm{~nm}$. The anatase titania crystal with peaks at $2 \theta$ of $25.3,38.0$ and 48.3 corresponding to (101), (004) and (200) phases respectively. With the decrease of grain size, XRD peak broadens. So, the broadness of the diffraction peaks at $400^{\circ} \mathrm{C}$ (a) shows the decrease of crystal size, at calcinations temperature of $600^{\circ} \mathrm{C}(\mathrm{b}), 800^{\circ} \mathrm{C}$ (b), and commercial P25 (d) diffractions peaks becomes narrower clearly showing the bigger size of particle due to the sintering effect which is illustrated in Table 1, however no rutile phase were observed even at higher temperature showing clear maintenance of good crystal framework of the anatase titania. In XRD patterns there were no impurities or reaction product peaks observed indicating that the obtained materials are in pure titania form.

Table 1. Variation of nano size $\mathrm{TiO}_{2}$ with Temperature

\begin{tabular}{|l|l|}
\hline Temperature & Crystal size $(\mathrm{nm})$ \\
\hline $400^{\circ} \mathrm{C}$ & $10.5 \mathrm{~nm}$ \\
\hline $600^{\circ} \mathrm{C}$ & $55 \mathrm{~m}$ \\
\hline $800^{\circ} \mathrm{C}$ & $100 \mathrm{~nm}$ \\
\hline
\end{tabular}

\subsubsection{TEM Analysis}

It is clear from TEM images in fig 2, the smaller particles with pores were observed in the $400^{\circ} \mathrm{C}$ calcined samples, however in the case of $600^{\circ} \mathrm{C}$ samples and $800^{\circ} \mathrm{C}$, scattered large particles of sizes $40-100 \mathrm{~nm}$ with tetragonal structures were observed, which clearly shows the interconnection of the mesopores were vanishing with the shrinkage in diameters of the pores at all over the surfaces. This is also consistent with the XRD patterns [17-19].

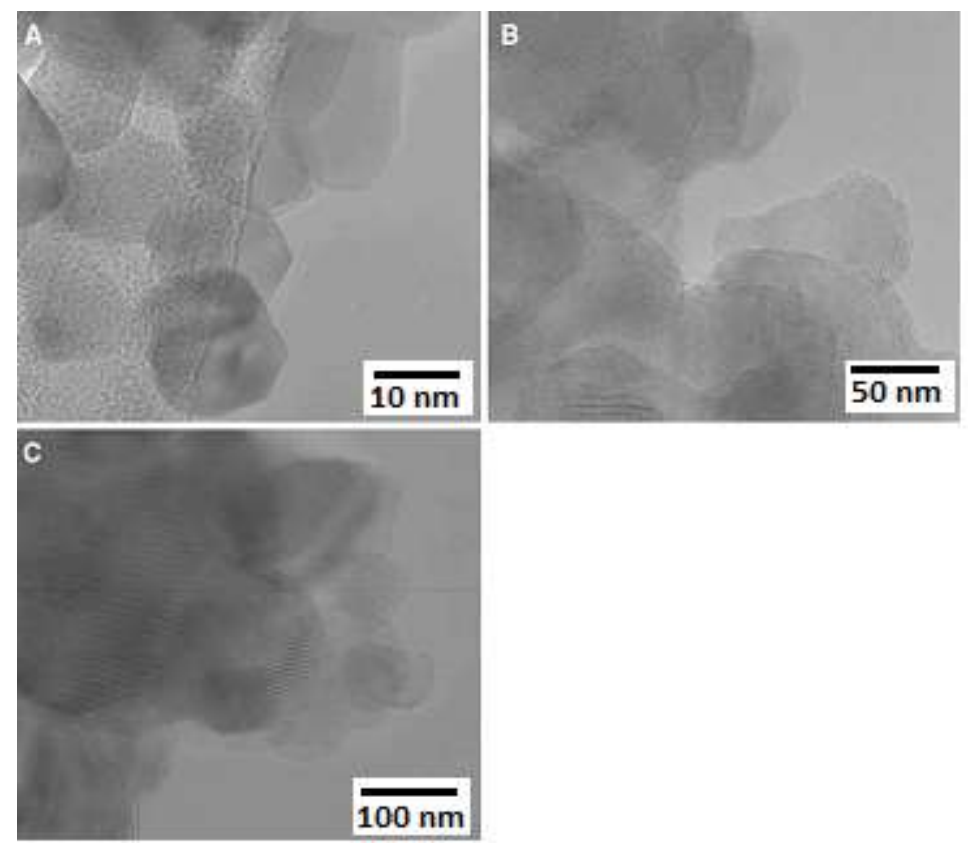

Fig.2: TEM images of $\mathrm{TiO}_{2}$ calcined at $400^{\circ} \mathrm{C}(\mathrm{a}), 600{ }^{\circ} \mathrm{C}(\mathrm{b})$ and $800^{\circ} \mathrm{C}(\mathrm{c})$ 


\subsubsection{SEM analysis}

Fig 3 shows the SEM analysis in which the particle size is around 10- $20 \mathrm{~nm}$ which is calcined at $400^{\circ} \mathrm{C}$. Since a crystallite can be defined by studying the orientation of the lattice fringes, one can see the average grain size in the synthesized $\mathrm{TiO}_{2}$ powder is about $10-20 \mathrm{~nm}$ in diameter, which is in good agreement with the calculated value from XRD analysis.

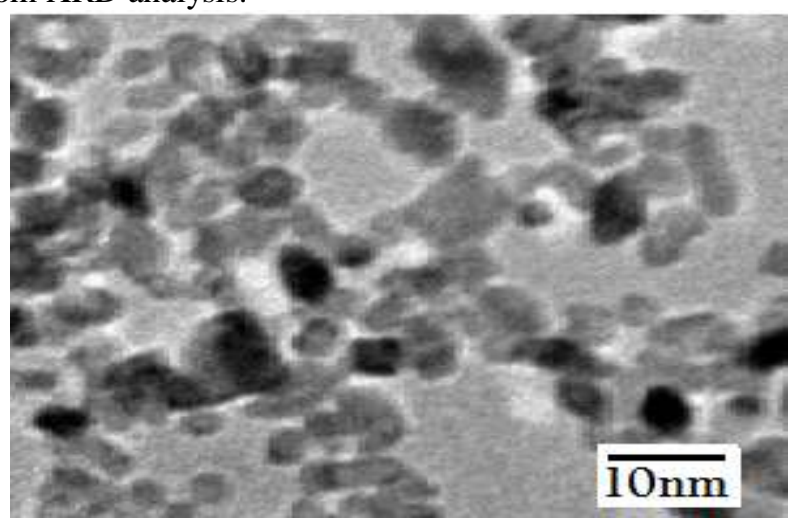

Fig.3. SEM images if $\mathrm{TiO}_{2}$ calcined at $400 \square \mathrm{C}$

\subsubsection{Photo catalytic activity}

These nano particles are coated in ITO plate and from this fabricated DSSC, the photocatalytic analysis is measured. Fig. 4 shows the photocurrent and photo voltage curves of the cells under the illumination (100 $\mathrm{mW} / \mathrm{cm} 2)$. The cell gave a high short circuit current $\left(\mathrm{I}_{\mathrm{SC}}\right)$ of $4.3 \mathrm{~mA} / \mathrm{cm}^{2}$, an open circuit voltage $650 \mathrm{mV}$ and a fill factor of $66 \%$, yielding over all conversion efficiency of $1.83 \%$ is determined using equation (3),

$$
F F=\frac{I m x V m}{I s c x V o c}
$$

\section{Equation (2)}

Where $\mathrm{FF}$ is the fill factor, $\mathrm{I}_{\mathrm{sc}}$ is short circuit current, $\mathrm{V}_{\mathrm{oc}}$ is the open circuit voltage, $\mathrm{I}_{\mathrm{m}}$ is the maximum current and $\mathrm{V}_{\mathrm{m}}$ is the maximum voltage,

$$
\eta=\frac{V o c \times J s c \times F F}{\operatorname{Pin}}
$$

Equation (3)

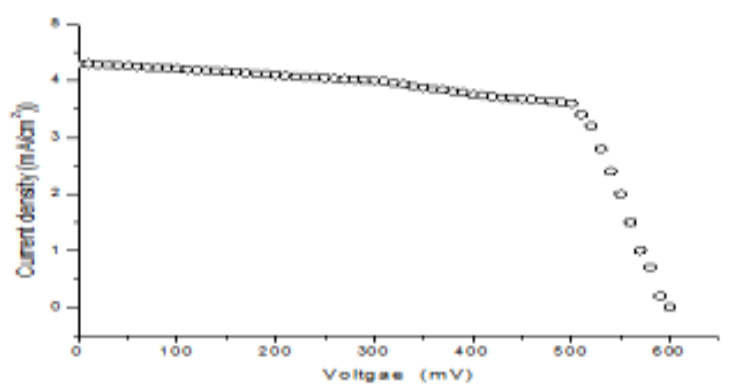

Fig. 4 Photovoltaic performance of $\mathrm{TiO}_{2}$ nanoparticles

Table 2. Photovoltaic performance of $\mathrm{TiO} 2$ nanoparticles

\begin{tabular}{|c|c|c|c|}
\hline $\operatorname{Voc}(\mathrm{mV})$ & $\mathrm{Jsc}\left(\mathrm{mA} / \mathrm{cm}^{2}\right)$ & $\mathrm{FF}$ & $\eta \%$ \\
\hline 650 & 4.3 & 0.66 & 1.83 \\
\hline
\end{tabular}

\section{Conclusion}

At the hydrolysis stage, the water quantity controls the generated grain sizes; with the slow addition and limited quantity of water we can control the morphologies of sol-gel derived materials. It is also well known that the high pore volume and large surface area of semiconducting materials are necessary to provide sufficient light and dye absorption, for better electrical connection with redox electrolytes, crystallinity and the photocurrent density. At the appropriate calcinations temperature, the $n$-heptane solvent can be removed and only mesoprous titania is observed. The calcined and optimized mesoporous substrate used in the fabrication of dye-sensitized solar cell which gave a fill factor of $66 \%$ with an energy conversion efficiency of $1.83 \%$ under 1 sun irradiation. The mesopore $\mathrm{TiO}_{2}$ substrate provide better surface for the absorption of dye, which improves 
light absorption efficiency and charge injection dye to conduction band of semiconductor leading to high efficiency anode material in dye-sensitized solar cells.

\section{Acknowledgment:}

I Thank Annamalai University, for allowing me to carry out this research and Bharathiar University, for permitting me to precede this work.

\section{References}

[1] B.O'Regan,M.Gratzel, "A low cost high efficiency solar cell based on dye- sensitized colloidal TiO 2 films", Nature 353(1991)737740 .

[2] M.K.Nazeeruddin,A.Kay,I.Rodicio,R.Humphry-Baker,E.Muller,P.Liska,N.Vlachopoulos,M.Gratzel, "Conversion of light to electricity by cis- $\mathrm{X}_{2}$-bis (2,20- bipyridyl-4,40-dicarboxalate) ruthenium (II) charge transfer sensitizers on nanocrystalline $\mathrm{TiO}_{2}$ electrodes", J.Am. Chem. Soc.115 (1993) 6382-6390.

[3] B.Y. Wei, H.M. Lin, C.C. Kao, A.K. Li, "Effect of calcinations on photo catalytic activity of TiO 2 nanopowders", J. Mater. Sci. Eng. 35 (2003) 64-69.

[4] Y.Li,J.Hagen, W. Schaffrath, P. Otschik, D. Haarer, "Titanium dioxide films for sensitized photovoltaic cells derived from a sol-gel process", Sol. Energy Mater. Sol. Cells 56 (1999) 167-174.

[5] M.Gratzel, "Dye sensitized solar cell”, Photoelectrochemicalcells, Nature414 (2001)338-344.

[6] E.W. McFarland, K. Tang, "A photovoltaic device structure based on internal $\mathrm{TiO}_{2}$ solar cells by chlorophyll derivatives", J. Phys. Chem. 98 (1994).

[7] M. Sakanoue, Y. Kinoshita, Y. Otsuka, and H. Imai, "Photocatalytic activities of rutile and anatase nanoparticles selectively prepared from an aqueous solution", Journal of the Ceramic Society of Japan, vol. 115, no. 1348, pp. 821-825, 2007.

[8] M. H. Habibi, N. Talebian, and J.-H. Choi, "The effect of annealing on photocatalytic properties of nanostructured titanium dioxide thin films", Dyes and Pigments,vol. 73, no.1, pp. 103-110, 2007.

[9] H. Han, X. Zhao, J. Liu, "Enhancement in photoelectric conversion properties of the dye-sensitized nanocrystalline solar cells based on the hybrid $\mathrm{TiO}_{2}$ electrode", Journal of The Electrochemical Society 152 (2005) A164-A166

[10] C. Grimes, G. Mor, O. Varghese, M. Paulose and K. Shankar, "A review on highly ordered, vertically oriented TiO2nanotube arra ys: Fabrication, material properties, and solar energy applications”, Solar Energy Materials and Solar Cells, 90, (2006) pp. 2011-2075.

[11] M. Wei, Y. Konishi, H. Zhou, H. Sugihara, H. Arakawab, "Utilization of titanate nanotubes as an electrode material in dye-sensitized solar cells", Journal of The Electrochemical Society 153 (2006) A1232-A1236.

[12] G.S. Kim, H.K. Seo, V.P. Godble, Y.S. Kim, O.B. Yang, H.S. Shin, "Electrophoretic deposition of titanate nanotubes from commercial titania nanoparticles: application to dye-sensitized solar cells", Electrochemistry Communications 8 (2006), 961-966.

[13] G.Rothenberger, P. Comte, M. Gratzel, "A Contribution to the Optical Design of Dye-Sensitized Nanocrystalline Solar Cells", Solar Energy Materials and Solar Cells58, (1999) pp. 321-336.

[14] Alam Khan M., Shaheer Akhtar, M., Bong Yang, O., 2010, "Synthesis, characterization and application of sol-gel derived mesoporous $\mathrm{TiO}_{2}$ nanoparticles for dye-sensitized solar cells", Solar Energy, 84, pp 2195-2201.

[15] M. Adachi, Y. Murata, I. Okada, S. Yoshikawa, "Formation of Titania Nanotubes and Applications for Dye-Sensitized Solar Cells", J. Electrochem. Soc. 150 [8] (2003) G488-493.

[16] C. Longo and M. DePaoli, "Dye-Sensitized Solar Cells: A Successful Combination of Materials”, J. Braz. Chem. Soc., 14 (6) (2003) pp 889-901.

[17] Martinson, Alex. B.F.;Hamann, T.W,Pellin, et al," New Architectures for Dye-SensitizedSolarCells,"Chem-Eur.J,vol.14,pp.44584467,2008

[18] W. Chan, "Titania nanotube array based photovoltaiccells", Appl. Phys. Lett.89 (2006) 023508-1-3.

[19] Green, M. A.; Emery, K.;Hishikawa,Y.; et al,"Solar cell efficiency tables,"ProgPhotoVoltaics, vol. 17,no,1,pp.85-94,2009.

[20] G. Nazmutdinova, S. Sensfuss, M. Schro“ dner, A. Hinsch, R. Satrawan, D. Gerhard, S. Himmler, P. Wasserscheid, "Quasi-solid state polymer electrolytes for dye-sensitized solar cells: Effect of the electrolyte components variation on the triiodide ion diffusion properties and charge-transfer resistance at platinum electrode", Solid State Ionics 177 (2006) 3141.

[21] D.Maheswari, P. Venkatachalam, R. Elangovan and K. Manoharan, "Formation and characterization o f nanosized tio 2 powder by sol-gel method”, International Journal of Nanotechnology and Applications, ISSN 0973-631X Volume 5, Number 2 (2011), pp. $129-136$ 